\title{
6.9
}

\section{England: local government and politics}

Outside the capital, England is one of the largest areas in the liberal democratic world that still lacks any form of regional governance and its own parliament and government, unlike the rest of the UK. Here, local authorities are the only other tier of elected government. Councils and mayors play a key role in the democratic life of cities, towns and regions. Colin Copus and the Democratic Audit team explore how democratically they have operated.

\section{What does democracy require of England's local governments?}

$\downarrow$ Councils and mayors should engage wide participation with local citizens in their own governance via voting in regular elections, and through consultation with individuals and interest groups.

$\downarrow$ Local voting systems should accurately convert parties' vote shares into seats on councils and should be open to new parties entering into competition. Voting systems for mayors and other single office-holders (like police commissioners) should maximise the ability of citizens to influence who gets elected.

$\downarrow$ As far as possible, consistent with the need for efficient scales of operation, local government areas and institutions should provide an effective expression of local and community identities and reflect communities of place that are important in civil society (and not be structured purely for administrative convenience).

$\downarrow$ Local government should be genuinely independent centres of decision-making, with sufficient financial resources and policy autonomy to be able to make meaningful choices on behalf of their citizens.

४ Within councils the key decision-makers should be clearly identifiable by the public and media. Council leaders and executive mayors should be subject to regular and effective scrutiny from the council members as a whole, and publicly answerable to local citizens and media.

Local government is typically subject to some supervision on key aspects of their conduct and policies; in England this is conducted directly by the UK government. However, councils and executive mayors should enjoy a degree of constitutional protection (or 'entrenchment') for key roles, and an assurance that they cannot 
simply be abolished, bypassed or their fundamental operations altered for solely partisan reasons by central government.

$\downarrow$ The principle of subsidiarity says that all policy issues that can be effectively handled in decentralised ways should be allocated to the lowest tier of government, closest to citizens.

\section{Recent developments: elections}

The local elections held in 118 areas across England in May 2018 were the first major test of public opinion following the surprising 2017 general election outcome. Both Labour and the Liberal Democrats gained councillors (compared with four years earlier), while the Conservatives suffered modest losses. Figure 1 shows that Labour won somewhat less than half of the seats, while the Liberal Democrats showed greater local resilience than their national poll ratings, claiming more than one in seven victories. The Conservatives won under a third of seats, as often happens to incumbent governments in English local elections. The results were broadly similar to those in May 2017.

Figure 1: The outcomes of the May 2018 elections in England (outside London)

\begin{tabular}{|c|c|c|c|}
\hline \multirow[b]{2}{*}{ Party } & \multicolumn{2}{|l|}{2018} & \multirow{2}{*}{$\begin{array}{l}\text { Cumulative } \\
\text { number of } \\
\text { councils } \\
\text { controlled }\end{array}$} \\
\hline & $\begin{array}{l}\text { Councillors } \\
\text { elected }\end{array}$ & $\begin{array}{l}\text { Percent of } \\
\text { seats elected }\end{array}$ & \\
\hline Labour & 1,225 & 47.5 & 53 \\
\hline Conservative & 824 & 31.9 & 39 \\
\hline Liberal Democrat & 390 & 15.1 & 6 \\
\hline Independents & 89 & 3.4 & 0 \\
\hline Green & 28 & 1.1 & 0 \\
\hline Residents & 21 & 0.8 & 0 \\
\hline UKIP & 3 & 0.1 & 0 \\
\hline Liberal Democrat & 1 & 0.0 & 0 \\
\hline $\begin{array}{l}\text { No overall control } \\
\text { councils }\end{array}$ & & & 20 \\
\hline Total & 2,581 & 100.0 & 118 \\
\hline
\end{tabular}

Source: Wikipedia 2018 
The parties' 'national equivalent vote shares' in 2018 (calculated by the BBC to allow the variations in which council areas are running elections in a given year) saw the top two parties tied on 35\% each at the UK level, with the Liberal Democrats on $16 \%$. In the 2017 local elections in England and Scotland (which took place a month before the June general election), the same national equivalent vote shares had put the Conservatives on $38 \%$ (winning many new seats), while Labour was on a historic low of $27 \%$; and the Liberal Democrats defending their local 'community' bases secured 18\% (more than double their eventual general election vote share a month later). The results of the May 2018 English local elections saw the three main British parties - Conservative, Labour and Liberal Democrats - end up holding some $92 \%$ of council seats across England. That figure shows a stunning penetration of local politics by national political parties who in turn shape the local political dynamic and aid the process of centralisation by pursuing national politics locally.

The government headed by Theresa May delivered on previous coalition and Cameron government promises of promoting devolution by creating elected executive mayors to operate on a sub-regional level. Designed to end the decade-long stasis on devolution within England, the new regional or metro mayors would take on functions previously run from Whitehall or quasi-government agencies. In 2017 mayoral elections were successfully held in six areas: turnouts were low, although this might be expected for brand new roles unfamiliar to voters. In 2018, the Sheffield City Region held its first metro mayoral elections, attracting a good turnout even though in this case the devolution plans were incomplete at the time of the election. These developments revived the somewhat flagging momentum towards more use of elected mayors (see below).

\section{Recent developments: spending pressures}

The impact of UK government austerity policies since 2010 has hit home hardest in English councils. The National Audit Office found that there had been an overall real-terms reduction in Whitehall funding for all English local authorities of 49\% since 2010/2011. Figure 2 shows that councils have chiefly, and understandably, cut back 'discretionary' spending which has affected services such as road maintenance, library, museum and leisure services and refuse collection. Councils have also implemented staff redundancies; sold off assets such as land and buildings; and spent financial reserves. Statutory duties, such as providing social care for old people and long-term ill and disabled people, and ensuring the safety of children, have been pruned too, but some central funding has been made available to ameliorate the worst effects. What we see here is local government as financially bound to and controlled by central government with little room for manoeuvre when it comes to replacing lost government funding. 


\section{Figure 2: Changes in English local authority spending on different services between 2010-11 and 2016-17}

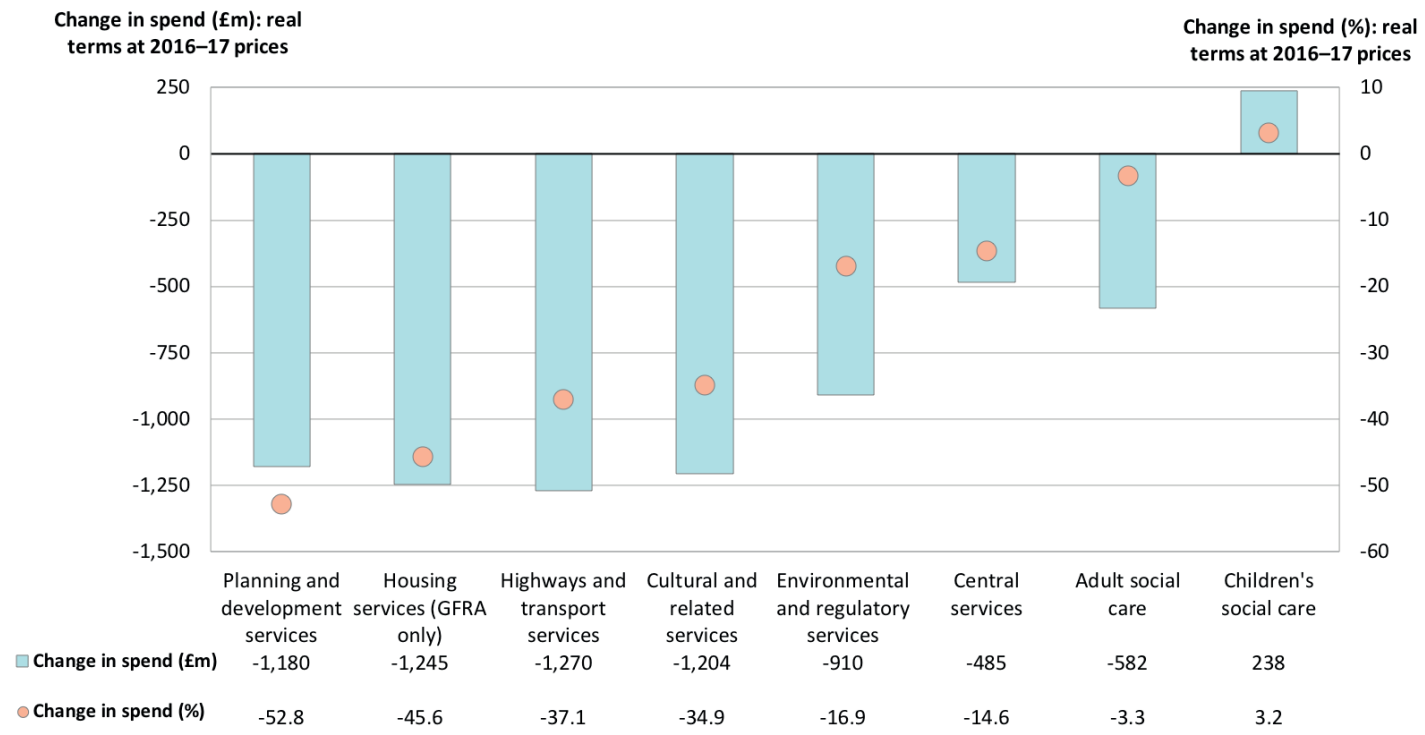

Source: Financial sustainability of local authorities 2018, National Audit Office, 2018, Figure 7

Notes: Data shown are net current expenditure. Adult social care includes transfers from healthcare bodies. GFRA is the General Fund Revenue Account. This provides revenue funding for the bulk of local authority services and is funded primarily by government grants, business rates and council tax. It is separate to the housing revenue account which is used to maintain local authority housing stock and is funded primarily through rental income.

The Local Government Association calculated in July 2017 that the then central revenue support grants of $£ 9.9$ bn would be reduced to just $£ 2.2$ bn by $2019-20$ on Whitehall's projections: 'Local government as a whole in England [including London] would have $£ 15.7 b n$ less central government funding by 2020 than it did in 2010'. Around half of all local councils will get no grant support at all.

Yet social-care spending pressures in particular have steadily increased with growing numbers of elderly people requiring support. Public anxieties about the deteriorating availability and quality of social care surfaced strongly in the 2017 general election campaign. During that campaign the Conservative manifesto included proposals (that were later dropped) for raising the capital a person could own before they were required to contribute to their own social care costs from $£ 23,000$ to $£ 100,000$. As social care is a devolved responsibility these proposals would have applied only in England.

At the same time local authorities' ability to raise council tax is restricted by Westminster and monies raised from business rates remain nationalised and handed over to the government. Currently, a long drawn out process of business rate retention is being undertaken by government, allowing local government to re-localise business rates so they are collected by and stay with the councils concerned. Such a process however, is a long 
way from being concluded satisfactorily for local government. In response to sustained austerity some councils are beginning to use their reserves to maintain essential statutory services. One experienced observer noted:

'Social care continues to be the main drain on resources as $66.2 \%$ of local authorities with social care responsibilities were forced to use their financial reserves in 2016/17... [Yet] even the richest county, Surrey, is more than $£ 100 m$ in debt, having used up its financial reserves and with no viable plan for the future.'

In early 2018, Conservative-controlled Northamptonshire County Council issued the first local government section 141 notice for 20 years. A 141 notice imposes strict financial controls on the council and prevents any expenditure except on statutory obligations (see below for more details). As a result of this move, itself prompted by financial decisions taken by the council, the Conservative government appointed two commissioners to oversee the county council. By mid summer it became clear that the authority's problems were extremely serious and indeed that:

'The scale of the cuts needed are huge. The council must make up $£ 70 m$ savings from its $£ 441 \mathrm{~m}$ budget over the next few months, and a further $£ 54 m$ savings in 2019-20. It must try to do this while demand for services soars, notably from children's services and social care services for elderly and disabled adults'.

A two-week investigation of the council in the shape of a 'best value' review conducted by a government-appointed independent commissioner (not the two commissioners mentioned above) concluded in a report that:

'the problems faced by NCC are so deep and ingrained that it is not possible to promote a recovery plan that could bring the council back to stability and safety within a reasonable time scale' (para 4.16). 'A way forward with a clean sheet, leaving all history behind is required', (para 4.17).

The report asserts that the above would be best achieved by abolishing the county council, and the seven well-performing district councils, and replacing them with two new unitary councils.

The government undertook a brief consultation process on this suggestion and if two of the eight Northamptonshire councils agreed to the reorganisation proposals all the councils would be replaced with two new unitary councils probably from April 2020. Most of the districts agreed with great reluctance to their own abolition. The move to unitary local government in Northamptonshire fits with a trend across England where previous 'two-tier council' structures (with county councils as the top tier above district councils) have been replaced by 'unitary' authorities. England already has the largest units of local government across Europe and the British government currently wants to see new unitary councils formed with population ranges of 300,000 to 800,000 inhabitants (see below). 


\section{Strengths, Weaknesses, Opportunities, Threats (SWOT) analysis}

\section{Current strengths}

The development of multi-party politics (before 2017) somewhat reduced the number of completely one-party councils, and cut the number of 'safe' councils. When councils are 'no overall control', cross-party coalitions are needed. This may increase the range of views being considered beyond those of a single party.

The voting system used for executive mayors is the supplementary vote, a system that gives citizens first and second choice votes (see Chapter 2.2). It ensures that the person elected must secure over $50 \%$ of the votes from 'eligible' votes in each contest. To win, candidates normally must 'reach out' beyond their own party's supporters to draw in second-vote backing from the supporters of other parties.

Councils are democratically elected, representative bodies. They provide an opportunity for over 18,000 people across England to take part in holding elected office. Local government provides avenues for participation in politics and for allowing for a wider range of people to hold elected office than simply the 650 elected to Parliament.

Local government is an institution that is able to provide a barrier between a powerful central state and local citizens and to at least attempt to attenuate the worst excesses of central policy.

\section{Current weaknesses}

Local council elections in England use plurality rule ('first-past-the-post') voting (see Chapter 2.1). It often produces severely disproportional election outcomes, especially over-representing the largest party in a local area. Some councils become completely one-party for long periods, and others are dominant-party systems, where the same party holds power for decades.

First-past-the-post elections sometimes provide for a clear winning party but it does not adequately reflect a wide range of political views. If local policy-making is to be a deliberative process where debate takes place in public, a more proportionate electoral system would strengthen local democracy.

The supplementary vote used for electing executive mayors and police commissioners is majoritarian not proportionate. If a voter's second preference is not for either of the top two candidates it will not count in the latter round of voting.

Local electoral turnout in England is among the lowest across Europe. It bumps uncomfortably along in the mid-to-high 30\% bracket - although turnout does increase when local elections are held on the same day as a general election.

Currently approximately $50 \%$ of local government revenue funding comes from the centre in the form of grants, many of which, such as grants received for schools, are ring-fenced and therefore cannot be used for purposes other than those set by the government. Central control leaves little discretion for local spending priorities to be realised, thus undermining the democratic legitimacy of local government. 


\section{Current strengths}

As locally elected representatives, councillors are located closer to the public than MPs and MEPs. They are, therefore, able to make policy decisions, or decisions about the provision of public services, in ways that closely reflect local needs and priorities.

\section{Current weaknesses}

Research shows that many voters in council elections are choosing parties to support on national lines. Hence local results may be influenced by the popularity of the government of the day in Westminster, rather than by local policies. Local elections are often reported in the media chiefly for what they can tell us about the national fortunes of the main political parties. These traits weaken the purpose of local elections, and the accountability of councillors to local voters.

The large size of English local government - compared to much of Europe - makes it remote from local citizens and undermines it as a truly local institution.

Local government can be re-shaped, restructured and re-organised at the whim of the centre, and its boundaries altered and reshaped, or particular councils abolished or merged, with little regard to the wishes of local communities. Thus, local government as a democratic component of the state is constitutionally weak.

Councils and mayors have borne huge reductions in spending, while their statutory duties remain extensive (especially in social care), and their ability to raise local taxes has been controlled by ministers. The financial problems experienced by Northamptonshire, and wider problems across all councils, underline the extent of service cutbacks made and the pressured role of local decision-makers.

Functions, powers, responsibilities and tasks of local government can be removed by the centre in Whitehall and placed with other agencies or bodies. UK ministers have interfered extensively and freely in local policy-making, removing functions and limiting councils' tax-raising powers. 


\section{Future opportunities \\ Central government's policy of devolution has seen major public service responsibility and some budgets devolved from the centre to new combined authorities. In May 2017 voters in six such combined authorities directly elected a mayor to head the new body. In 2018, Sheffield City Region followed. It is likely that further devolution to local government, through combined authorities, will form a part of government thinking.}

The Brexit negotiations designed to ensure the repatriation of powers, responsibilities, finance and sovereignty lost as a result of EU centralisation can be used to accelerate devolution to local government. A strong local government voice at or around the negotiations could make sure that repatriated powers do not stop at Westminster and Whitehall, but flow down to local government and to parish-level government.

Local government's experiences and practices of citizen engagement and devolution to local communities can bolster its support, and engage citizens in policy-making and local decisions far more effectively than similar attempts by central government.

There may be scope in the Brexit negotiations for improvements in how councils achieve funding. Currently English local authorities receive 70 different forms of EU funding managed by different local government departments. The processes involved can be confusing, slow and bureaucratic. Taking back control within the UK will speed things up and produce simplified decision-making processes.

\section{Future threats}

Local government, as a creature of statute and with no independent right to exist, is under constant threat of centralising governments or the centralising tendencies of the civil service.

Local government operates in an environment where it competes with a wide range of external agencies and bodies, which spend public money, make public policy decisions and affect the well-being of local communities but do so without a democratic mandate. Local government is open to the centre removing its responsibilities and functions and placing them with unelected bodies.

The low fiscal discretion available to local government will continue to hinder its ability to respond to economic change and austerity policies implemented by the centre.

There are no guarantees that the UK government will pick up and replace EU funding to councils as part of the Brexit process. The two-stage process envisaged by ministers, of first repatriating powers within the UK and only thereafter considering whether any of them should be delegated down to local authorities, is likely to re-centralise controls in Whitehall, certainly for the short term. 'Henry VIII' powers in Brexit legislation will also give ministers far more discretion in how they implement executive powers. 


\section{Elected executive mayors}

Throughout the 20th century, English mayors were honorific office holders, chairing council meetings and opening civic events, but otherwise devoid of power. Local political power instead lay with the majority party group on the council whose leadership typically formed a 'submerged executive' little known to citizens and not visible to the local media.

The Blair government changed this historic pattern through legislation passed in 1998 to introduce a powerful executive mayor for Greater London. The first mayor was directly elected by voters in 2000 using the supplementary vote (SV), which guarantees that the mayor has clear majority support in their area (see Chapter $\mathbf{2 . 2}$ for how this voting system works). The success of this innovation lead to local citizens anywhere in England gaining the power through the Local Government Act 2000 to petition to hold a binding referendum on whether to create an elected mayor with executive powers for their area, and thus be able to directly choose the political head of the council, again using SV. Figure 3 shows the councils where directly elected mayors exist and the year in which they were introduced. A legislative change in 2007 allowed councils to resolve to move to a mayoral system of governance without a referendum, but only Leicester and Liverpool have used this method. So far there have been 53 referenda and currently there are 16 directly elected mayors heading traditional English councils. Two authorities (Hartlepool and Stokeon-Trent) had directly elected mayors but subsequently abolished the office.

Figure 3: Elected executive mayors in England in municipalities and the new metro/regional areas

\section{Elected mayors in conventional local authorities}

Bedford, Doncaster, Hackney London borough (LB), Lewisham LB, Newham

LB, Mansfield, Middlesbrough, North Tyneside, Watford

Torbay

Tower Hamlets LB

Leicester

Bristol, Liverpool, Salford

Copeland

\section{Regional or metro-mayors}

Cambridgeshire and Peterborough; Greater Manchester;

Liverpool City Region; Tees Valley; West of England; West Midlands

Sheffield City Region

\section{Established}

2002

2005

2010

2011

2012

2015

\section{7}

2018

Direct election of local office-holders was adopted by the coalition government for the police and crime commissioners (PCCs), introduced across England and Wales in November 2012. These SV elections attracted only a 15\% turnout and of the 37 PCCs in England, when the Conservatives won 15, Labour 12 and independent candidates won a not inconsiderable 10 PCCs. In May 2016, the second PCC elections were held alongside the local elections. This time 21 Conservatives, 16 Labour, 3 independents and 2 Plaid Cymru commissioners were elected (see Chapter 2.2). 
In 2017, the Conservatives' general election manifesto proposed to scrap SV elections for police commissioners and all elected mayors, and replace it with first-past-the-post, a move that would dramatically impair these office-holders' legitimacy. The advent of a hung parliament has meant that such a move is unlikely to be given much priority.

\section{Regional or metro-level executive mayors}

Since May 2017, a new type of mayor and a new type of sub-national political institution has been introduced, the combined authority, in the seven areas shown in the bottom half of Figure 3, with directly elected regional or metro mayors. The devolution initiative stemmed from the Local Democracy, Economic Development and Construction Act 2009 and the Cities and Local Government Devolution Act 2016.

As the name suggest, the combined authorities are groupings of existing local authorities that have negotiated a devolution deal with the government. The key consequence of each deal is that the councils acting together receive devolved responsibilities for a range of services and devolved budgets. Several metro mayors (including Manchester) have taken over the role previously filled by police and crime commissioners in their area, and some will seek to better integrate social care with regional NHS provision - giving them substantial roles and influence across public services. The significance of these new types of sub-national combination of authorities and the directly elected mayors that head them cannot be overstated. They are a new way of the centre attempting to devolve powers and functions, and early developments were promising.

The first elections for the new mayors were held successfully in 2017 and 2018, attracting an encouraging turnout for first-time elections (see Chapter 2.2). Some mayoral contests attracted 'big hitter' politicians as candidates. The former Cabinet minister Andy Burnham won the 2017 Greater Manchester contest for Labour against the run of polls, and was quickly prominent in the response to the Manchester Islamist terror bombing. The former John Lewis executive Andy Street won the West Midlands for the Conservatives, while prominent Labour MP Dan Jarvis easily won in 2018 in Sheffield.

But as with all sub-national bodies within England, they exist at the behest of the centre, so Whitehall's willingness to devolve effective powers remain to be tested. At times the 'devolution deals' appear to lack imagination and the process of negotiating deals has been a contested one among the councils as was the case in Sheffield City Region. The protracted debates about realising a proposed mayor for the whole of Yorkshire demonstrates the complex problems involved in bringing council areas together for regional-level functions as well as the intensity of local politics.

Some politicians - notably the Blair government - have made siren calls for regional government in England. While England lacks its own Parliament such proposals would simply divide England, breaking it into disputing factions. There is no strong regional identity in England that replicates that found in other European countries, and in 2004 when the Blair government gave voters of the North East of England - deemed by some to have the strongest regional identity - a referendum on regional government almost 78\% of voters rejected the idea. Moreover, the administrative regions of England do not reflect 
real places in the same way as German Länder or Spanish and Italian regions. Indeed, six of the eight English regions are merely compass points - north-east, south-west - that just so happen to reflect NUTS 1 regions within the EU rather than 'real' parts of England. England also lacks its own Parliament, government and First Minister, unlike Scotland, Wales and Northern Ireland, and therefore England is at a great disadvantage when faced with the rest of the UK when it comes to a distinct English voice in the competition for resources from the UK government. It is a disadvantage that no type of local government or sub-regional entity can overcome no matter how local government may be reorganised.

\section{Reorganisation of local authority areas}

There has been a long-term and consistent trend in English local government, almost since the creation of recognisably democratic councils by the 1835 Municipal Corporations Act, towards larger and therefore fewer, units of local government. The trend continued in a semi-ad hoc fashion until the Local Government Act 1972 reduced the number of English councils from just over 1,200 to 377 and reduced the number of councillors by around $50 \%$ to approximately 20,000 . Since then further ad hoc reorganisations have taken place, further reducing the number of councils to 352 (with further reduction in councillor numbers to around 18,000).

Figure 4 shows the most recent reorganisation carried out in 2009 (under the Brown Labour government), which focused in more rural areas with two tiers of district and county councils. These changes saw 44 existing councils abolished and replaced by just nine new councils with a loss of over 1,300 councillors, a $63 \%$ reduction in the areas affected.

Figure 4: Changes made in the 2009 reorganisation

\begin{tabular}{|l|l|r|r|}
\hline County area & Main reform & $\begin{array}{l}\text { Old } \\
\text { councils }\end{array}$ & $\begin{array}{l}\text { New } \\
\text { councils }\end{array}$ \\
\hline Bedfordshire & $\begin{array}{l}\text { County council abolished. Two districts } \\
\text { now unitary authorities }\end{array}$ & 3 & 2 \\
\hline Cheshire & $\begin{array}{l}\text { County council abolished. Two districts } \\
\text { now unitary authorities }\end{array}$ & 7 & 2 \\
\hline Cornwall & Unitary county, 6 districts abolished & 7 & 1 \\
\hline Durham & Unitary county, 7 districts abolished & 7 & 1 \\
\hline Northumberland & Unitary county, 5 districts abolished & 6 & 1 \\
\hline Shropshire & Unitary county, 5 districts abolished & 5 & 1 \\
\hline Wiltshire & Unitary county, 4 districts abolished & $\mathbf{4 4}$ & $\mathbf{9}$ \\
\hline Total & & 7 & 1 \\
\hline
\end{tabular}

The unitary debate continues, with austerity and cost-saving often being used as a rationale for abolishing the two-tier system, replacing it with a county-based unitary model. Areas such as Buckinghamshire, Dorset, Leicestershire, Nottinghamshire and Oxfordshire, to name a few, are in a reorganisation battle (some are further on in that battle than others). The first shot in such wars is normally fired by a voracious county council seeking to abolish 
its district councils and take on their responsibilities and functions. Some districts however, are not going meekly to the slaughter as in Northamptonshire mentioned above, but are campaigning to keep local government close to communities.

Council reorganisations in England over many decades have created some of the largest units of local government across liberal democracies. They were justified in terms of efficiency and creating a simpler structure of unitary authorities, that is more understandable for citizens. While evidence does not consistently show that larger councils will be more efficient or effective, the British government presses ahead with its unitarisation policies, regardless. Fewer councils mean fewer elected members which means less participation by people in local politics, a greater workload for the remaining members and a greater distance between them and the citizens they represent. In addition, larger units of local government are more remote from the public than the smaller units they often replaced, which can create more communicative distance between councils and citizens. Subsequent reorganisations of local government, and boundary reviews, have led to a piecemeal reduction of the number of councillors, in a 'stealth process' that some have argued lacks transparency and any democratic rationale. Critics argue that as English local government units get bigger and are less proximate to citizens, so citizens will tend to disengage and to feel less politically efficacious.

\section{Local cabinets and scrutiny committees}

The historic patterns of how councils were run in England changed with the Local Government Act 2000. Prior to that all councillors were collectively engaged in decisionmaking through committees and no single councillor legally held decision-making powers. In reality however, the majority party group of councillors would get their preferred decisions made in committee. Committee chairs would also often meet together privately, or with officers and act as a form of 'submerged' or nascent cabinet, whose existence voters were largely unaware of.

From 2000 onwards, all councils were obliged by law to distinguish between councillors holding executive positions within a cabinet headed by an executive leader (or directly elected mayor), and the remainder of the council membership. Executive councillors hold portfolios and if the council decided, can have individual delegated authority. Councillors outside the cabinet no longer have day-to-day decision-making powers, but sit on overview and scrutiny committees, charged with holding the executive to account, reviewing policy and decisions, or indeed, holding to account and reviewing the actions of organisations beyond the council. Overview and scrutiny committees, however, cannot make decisions, only produce reports and recommendations for others to consider.

\section{The Localism Act 2011}

The opening section of the Localism Act 2011 provides that 'a local authority has power to do anything that individuals generally may do' unless they are specifically prohibited in legislation. However, this relatively new 'general competence' power does not free local government from oversight by Whitehall departments, who have been less than 
enthusiastic in embracing the idea of new freedoms for local government. Indeed, the power does not fundamentally undermine the structure of public law and how councils are restricted in their ability to act. A conflict exists here between the legalistic view of local government and a political/governing attitude to local government. Yet, if English local government is to have any chance of genuinely focusing local views, and having governing autonomy to act as it thinks fit to solve the issues it faces, then the general power of competence is a step in the right direction.

In 2013 the Political and Constitutional Reform Committee, then chaired by Graham Allen MP (and not re-formed after the 2015 election), published a report on the prospects of codifying the relationships between central and local government. It included a manifesto (pp.1-9) by this author, outlining how genuine localism and autonomy could be introduced. It proposed radically new local law-making powers for councils, constitutional protection against being abolished or reorganised, substantial tax-raising powers and financial independence from central government. The manifesto also envisaged an English Parliament with much the same powers as the Scottish Parliament (except for the local autonomy provisions above), including safeguards for local citizens to control local voting methods and changes in how councils are run by local referenda. Implementing such a manifesto, or even part of it, would considerably enhance the democratic strength of local government and recognise it as a permanent partner with Whitehall in the overall government of England.

\section{Conclusions}

The striking weakness of English regionalism may be partly due to citizens' strong local loyalties to their existing councils (as well as to Englishness). Local authorities have done a remarkable job in trying to protect their communities from the worst consequences of austerity policies. But councils and mayors have no constitutional protection from Whitehall interference, and depend heavily on central government grants. Their relative weakness as a tier of government has been compounded by the 'nationalisation' of the UK press and media system and the decline of the local press (see Chapter 3.3), plus the dominance of UK national parties in 'first-past-the-post' local elections (see Chapter 2.1) that only weakly relate parties' seats to their vote share.

Colin Copus is Emeritus Professor of Local Politics De Montfort University and a visiting Professor at the University of Ghent. 